\title{
THE SUITABILITY OF WELL WATER FOR DOMESTIC PURPOSE, IN GWAGWALADA AREA COUNCIL ABUJA NIGERIA
}

\section{EPHRAIM BRIGID BASSEY, OGAH T. A., MAGAJI J. I. AND OLADEINDE OLUFEMI STEPHEN}

(Received 26 April 2021; Revision Accepted 24 May 2021)

\begin{abstract}
Water wells are usually dug by artisans who lack professional skills. Such wells are used at various homes in Gwagwalada Area Council of Abuja for domestic purpose, on the assumption that underground water is safe. Thus, the suitability of such well water was assessed. The objectives were to assess their properties and compare with regulatory standard for domestic purpose. Thirty (30) water samples were purposely collected from six wards (Dobi, Ibwa, Paikon-Kore, Tungan Maje, Zuba and Ikwa). Five water samples were randomly collected from each ward for laboratory analysis. Laboratory results were statistically analyzed using range, mean, correlation and multiple determination coefficients. Suitability of water properties for domestic purposes was determined by comparing range and mean values with NSDWQ and WHO standard for domestic uses. Result showed that the concentrations of water properties ranges as follows: temperature $\left(26.59-30.73^{\circ} \mathrm{C}\right), \mathrm{pH}(7.17-8.23)$, electrical conductivity EC (222-354 $\mu \mathrm{s} / \mathrm{cm} 3)$, TDS (12.14-21.54mg/l), Turbidity (0.29-0.93NTU) hardness (13.58-39.72mg/l), chloride $\mathrm{Cl}-(4.29-8.93 \mathrm{mg} / \mathrm{l})$, Fe $(0.54-0.71 \mathrm{mg} / \mathrm{l})$ and $\mathrm{Cu}(0.02-0.06 \mathrm{mg} / \mathrm{l})$.Water samples generally had low electrical conductivity $\left(222-354 \mu \mathrm{s} / \mathrm{cm}^{3}\right)$, and mineral nutrients but elevated concentration of some heavy metals. The twenty- three water quality parameters tested could explain $96 \%$ of the overall water quality leaving only $4 \%$ unexplained. All the samples fell short of regulatory standard in terms of $\mathrm{EC}, \mathrm{Fe}$ and $\mathrm{Cu}$ while well water from lkwa fell short of many heavy metals for domestic purpose. It was concluded that well water in Gwagwalada Area Council are not potable. Thus, treatment before direct consumption and precautionary use of well water were recommended for the residents.
\end{abstract}

KEYWORDS: Water quality, Heavy metals, Water pollution, Well,

\section{INTRODUCTION}

The provision of safe drinking water to the majority of the world's population is one of the greatest global challenges. In Nigeria, majority of the rural populace do not have access to tap water and therefore, depend on well, stream and river water for domestic use (Adeniyi and Abdullateef, 2019). Despite that, the expansion of population and economic activities especially in an urban setting like Abuja, Nigeria, has made surface water completely unsafe for domestic purpose (Chokpa, 2018). Consequently, many have resorted to underground water sources such as borehole and well water, with the notion that underground water is safe for drinking purpose. However, the safety of underground water is still questionable due to possible percolation of leachates from waste dumps and other sources of contamination like sewage system. Though, there is proliferation of borehole drilling in the Federal Capital
Territory in general (Federal Capital Development Authority (FCDA, 2018), well water is still the most common underground water source in the study area. Water quality refers to the suitability of water for certain purpose; hence quality of drinking water is the suitability of water for drinking and domestic uses. A good quality (safe) drinking water is that which is aesthetically acceptable and does not contain pathogenic agents and dangerous chemical substances. Domestic uses (drinking, cooking, bathing, washing and sanitation) are the fundamental and most important uses of water that must meet some standard, both in quantity and quality (Awaisu, et al., 2019). Safe drinking water must be riskhealth free such that a well-informed individual need not be concerned about it, nor find any rational basis to change his/her behavior to avoid a negligible but nonzero risk (World Health Organization WHO, 2010). Drinking water must be 'wholesome' and this is defined in law by standards for a wide range of substances,

Ephraim Brigid Bassey, Geography Department Nasarawa State University Keffi

Ogah T. A., Geography Department Nasarawa State University Keffi

Magaji J. I., Geography Department Nasarawa State University Keffi

Oladeinde Olufemi Stephen, National Space Research and Development Agency (NASDRA) COPINE

Obafemi Awolowo University, lle Ife, Osun State. 
organisms and properties of water in regulations. The standards are set to be protective of public health and the definition of wholesome reflects the importance of ensuring that water quality is acceptable to consumers (Jidauna et al., 2017). There are different standards to determine the suitability of water for certain uses.

However, WHO standard is the most acceptable and commonly used. Thus, the World Health Organization Guidelines for Drinking Water Quality (WHO, 2010; 2015) were adopted for this study.

Water quality assessment is a very complex subject, in part because water is a complex medium, intrinsically tied to the ecology of the planet (Kolo et al., 2009). To determine water quality therefore, several parameters must be examined. The complexity of water quality assessment as a subject is reflected in the many types of measurements of water quality. Among the key parameters listed by WHO (2011) for determination of water quality for domestic use are conductivity, $\mathrm{pH}$, Color of water, taste and odour, turbidity, total suspended solids (TSS) and hardness.

Public in general, judges the quality of water supplied based on its appearance, taste, and odour at the point of its use. Although appearance, taste, odour etc are useful indicators of the quality of drinking waters, their presence does not necessarily make water unsafe to drink. In the same way, the absence of any unpleasant qualities does not guarantee water to be safe for consumption (Okoro et al., 2017). However, suitability in terms of public health is determined by microbiological, physical, chemical and radiological characteristics. Also a number of chemical contaminations (both organic and inorganic) are found in water. These causes health problems in the long run and therefore detailed analysis are warranted.

Thus, several researches have been carried out on water quality and its safety for domestic use. Consequently, there are lots of literature on water quality and safety. For example Jidauna et al., (2017) assessed water quality of selected water sources in Dutsinma town, Katsina State, Nigeria. Result showed that tap water has $\mathrm{pH}$ value (4.61) which is acidic while the rest are within the approved standard. Dam had the lowest electrical conductivity $(50.25 \mu / \mathrm{cm})$ and $56.15 \mathrm{mg} / \mathrm{l}$ for total dissolve solute. However, calcium concentration appears lower for all water sources when compared to the WHO and SON standards for water quality. It was recommended that periodic monitoring of water quality and effective waste management system are required to improve the general water quality in the town. Then, by implication, this study is necessary based on the recommendation of Jidauna et al., (2017).

Shalom et al., (2011) assessed water quality in Canaan land Ota Southwest Nigeria. In this study, water points in Canaan land, Ota, and nearby lju River were analyzed for biological and physicochemical properties including heavy metal content. They reported that the water samples were slightly acidic $(5.96-6.54)$ except the bottled/ sachet Hebron water and lju River water. The results were compared against drinking water quality standards laid by World Health Organization (WHO) and Nigerian Standard for Drinking Water (NSDW). The potable water samples were within the standards for consumable water and so are considered safe for human consumption. The surface waters, on the other hand, have high levels of total dissolved solids, conductivity and salinity. The BOD of the effluent water showed that the water was contaminated and the use of the water for domestic purposes by the inhabitants could lead to hazardous side effects.

Chukwu (2008) reported a study on the ground water contamination from abattoir waste in Minna, Niger State. The examined wells with indicated physical, chemical and organic parameters that surpassed the upper limits set by WHO. The waters are by and large hard, containing elevated concentrations of calcium carbonate (CaCO3), magnesium carbonate (MgCO3), sulfates, nitrates, phosphates and heavy metals. Similarly, Ezeribe et al., (2012) found that most of the parameters determined did not exceed the permissible limit of the World Health Organization (WHO, 2006). Turbidity levels, nitrates and fluoride concentrations in Dass, and Langtang North exceeded the WHO standard specified for drinking water.

Okoro et al., (2017) carried out a comparative analysis of three borehole water sources in Nsukka urban area, Enugu State, Nigeria. Samples were collected from three locations within the area and analysed for some physico-chemical and microbial parameters, which were compared with the Nigerian Standard for Drinking Water Quality (NSDWQ) and the World Health Organization (WHO) standard for compliance evaluation. The physicochemical parameters included $\mathrm{pH}$, Hardness, Total Solids, Alkalinlity, Turbidity, Sulphate, Phosphate, Silica, $\mathrm{Cu}, \mathrm{Pb}, \mathrm{Fe}$, Residual Chlorine and Chloride with results ranging from 6.29-6.43, 15-483mg/l, 41.4$227.2 \mathrm{mg} / \mathrm{l}, \quad 0.2-0.5 \mathrm{NTU}, \quad 12.48-17.92 \mathrm{mg} / \mathrm{l}, \quad 0.6-1.3 \mathrm{mg} / \mathrm{l}$, $0.12-0.29 \mathrm{mg} / \mathrm{l}, 0.00-0.25 \mathrm{ppm}, 0.1630-0.2853 \mathrm{ppm}$ and $64.98-78.61 \mathrm{mg} / \mathrm{l}$ respectively. All the physicochemical parameters were within the standard limits recommended by $\mathrm{WHO}$ and $\mathrm{NSDWQ}$, except for the following: $\mathrm{pH}$, Hardness and $\mathrm{Pb}$.

Behailu et al., (2017) determined the level of common cations, anions, heavy metals and physical parameters in drinking water supply system in Konso and its surrounding area, Southwestern Ethiopia. Water samples were collected from 23 different locations in the area where there is hand pump or motorized supply system that are used for drinking purpose. Collected samples were analyzed for physicochemical parameters including total alkalinity, Temperature, $\mathrm{pH}$, Electrical Conductivity, Total dissolved solids, Turbidity, Alkalinity, Total hardness and Total suspended solids. Common cations $\left(\mathrm{Li}^{+}, \mathrm{K}^{+}, \mathrm{Na}^{+}, \mathrm{Ca}^{2+}\right.$ and $\left.\mathrm{Mg}^{2+}\right)$, Common anions $\left(\mathrm{NO}^{3-}, \mathrm{SO}_{4}{ }^{2-}, \mathrm{PO}_{4}{ }^{2-}, \mathrm{F}^{-}\right.$and $\left.\mathrm{Cl}^{-}\right)$and Heavy metals $(\mathrm{Pd}$, $\mathrm{Ni}, \mathrm{Mn}, \mathrm{Pb}, \mathrm{Co}, \mathrm{Zn}, \mathrm{Cu}$ ) were analyzed. The results were compared with some national and international standards for drinking water. Accordingly, the results obtained showed that most of the physical and some common ions and heavy metals were within the accepted range of the guideline recommended by WHO. Samaila et al., (2015) assessed water quality of hand dug wells used for domestic purposes in Vandekya, Benue State, Nigeria to determine the suitability of well water in the area for domestic use. The study recorded that most of the well waters had their properties within the permissible limit for drinking purpose set by World Health Organization. But some wells have turbidity and iron concentration greater than the WHO limit for drinking water.

Despite the abundance of literature in the topic of water quality, little attention has been paid to well water, which 
currently serves many domestic purposes including drinking in Gwagwalada Area Council Abuja, Nigeria. Thus, there is need to assess the suitability of well water for domestic purpose, in Gwagwalada Area Council Abuja, Nigeria as carried out in this study. The objectives were to assess the properties of well water and determine the suitability of well water properties for domestic purpose in Gwagwalada Area Council Abuja, Nigeria.

\section{MATERIALS AND METHODS}

Gwagwalada Area Council is one of the six area councils in the Federal Capital Territory which, according to the master plan of the FCT, is designated as the industrial zone. Gwagwalada is located between Latitudes $8^{0} 55^{\prime}$ and $9^{\circ} 00^{\prime}$ North and Longitudes $7^{\circ} 00^{\prime} \mathrm{N}$ and $7^{\circ} 05^{\prime} \mathrm{E}$. The Area Council has ten political wards (Adeniyi and Abdullateef, 2019). The centrality of the town in relation to other Area Council Headquarters makes it influential and important in various socioeconomic activities. It is where the University of Abuja, Abuja University Teaching Hospital and School of the Gifted are located. Consequently, there has been influx of people to Gwagwalada Area Council in recent years. This also increased the water demand which the Government have not been able to meet the demand. Thus, households have resorted to sourcing underground water by digging wells to have access to water for domestic uses.

Thirty (30) water samples were collected from wells in six purposely selected wards in the in the study. The selections of the wards for well sampling were based on heavy reliance of well water for domestic use among wards that currently lack public water supply. Thus, Dobi, Ibwa, Paikon-Kore, Tungan Maje, Zuba and Ikwa were selected. These wards according to the report of (Adeniyi and Abdullateef, 2019) are not linked with public tap water supply. Five water samples were randomly collected from each of the six selected wards and taken to laboratory for analysis. The selections of wells sampled were based on use. Wells used for drinking purpose was given preference to others. The uses and conditions of wells sampled were carefully observed at the course of sampling.

The water samples were stored in $150 \mathrm{cl}$ plastic bottles, pre-cleaned with distilled water and rinsed three times with the sample water. Each sample was labeled with the name of the ward and transported immediately to the Abuja Water Board Laboratory for analysis.

\section{RESULTS AND DISCUSSIONS}

Result in table 1 present the physical and chemical properties of well water in the study area as follows:

\section{Temperature and $\mathrm{pH}$}

Temperature recorded ranged from $26.59-30.73^{\circ} \mathrm{C}$ with mean value of $28.04^{\circ} \mathrm{C}$. The concentration of $\mathrm{pH}$ in the water ranged from 7.17-8.23 with mean value of 7.81. The range of $\mathrm{pH}$ is similar to the report of Tsegay and Haftom (2016) that reported 7.14 - 8.64 in reservoir water.

\section{Electrical Conductivity (EC)}

The concentration of electrical conductivity in water samples ranged from $222-354 \mu^{\mathrm{s}} / \mathrm{cm}^{3}$ with mean value of $261.00 \mu^{\mathrm{s}} / \mathrm{cm}^{3}$. The concentration of electrical conductivity is highest $\left(354 \mu^{\mathrm{s}} / \mathrm{cm}^{3}\right)$ in sample collected
Dobi while the water sample collected from lkwa has the least concentration of electrical conductivity (240 $\left.\mu^{\mathrm{s}} / \mathrm{cm}^{3}\right)$.

\section{TDS, TSS and Turbidity}

The concentration of Total Dissolved Solids (TDS) ranged from $12.14-21.54 \mathrm{Mg} / \mathrm{l}$ with mean value of 14.56 $\mathrm{Mg} / \mathrm{l}$. The Total Suspended Solids ranged from 0.26 $1.33 \mathrm{Mg} / \mathrm{l}$ with mean value of $0.49 \mathrm{Mg} / \mathrm{l}$. This is in close range with the report of (Tsegay and Haftom, 2016) that reported $0.91-1.77 \mathrm{Mg} / \mathrm{l}$ in reservoir water. Turbidity ranged from $0.29-0.93 \mathrm{Mg} / \mathrm{l}$ with mean value of 0.46 $\mathrm{Mg} / \mathrm{l}$.

\section{Total Hardness}

The concentration of total hardness ranged from 13.58$39.72 \mathrm{Mg} / \mathrm{l}$ with mean value of $23.87 \mathrm{Mg} / \mathrm{l}$. The concentration of total hardness in the water samples is below the report of APHA (2005) but above the report of Akpan-ldiok et al (2012). APHA (2005) reported a range of 29-94 Mg/l and Akpan-Idiok (2012) reported a range of $6.41-19.20 \mathrm{Mg} / \mathrm{l}$.

Minerals Nutrients (K, Na, Cl-, Mg, $\mathrm{Ca}$ and NO-3)

The concentrations of minerals nutrients in well water in the study area are low except for Chloride, magnesium and calcium. The concentrations are as follows: Potassium (K) ranged from 3.05-5.09 Mg/l with mean value of $4.10 \mathrm{Mg} / \mathrm{l}$. Sodium ( $\mathrm{Na}$ ) ranged from 4.11 $5.65 \mathrm{Mg} / \mathrm{l}$ with mean value of $5.08 \mathrm{Mg} / \mathrm{l}$. Chloride $(\mathrm{Cl}-)$ ranged from $4.29-8.93 \mathrm{Mg} / \mathrm{l}$ with mean value of 6.62 $\mathrm{Mg} / \mathrm{l}$. Magnesium (Mg) ranged from 9.03-17.86 Mg/l with mean value of $12.53 \mathrm{Mg} / \mathrm{l}$. Calcium $(\mathrm{Ca})$ ranged from 8.04-21.86 Mg/l with mean value of $14.34 \mathrm{Mg} / \mathrm{l}$. Nitrate (NO3) ranged from $1.47-2.53 \mathrm{Mg} / \mathrm{l}$ with mean value of 1.73Mg/l. Phosphate (PO4) ranged from 0.27-0.73 Mg/l with mean value of $0.51 \mathrm{Mg} / \mathrm{l}$. The mean concentrations of mineral nutrients\{potassium $(\mathrm{K}), \operatorname{sodium}(\mathrm{Na})$, chloride $(\mathrm{Cl}-)$, magnesium $(\mathrm{Mg})$, calcium $(\mathrm{Ca})$, nitrite $\left(\mathrm{NO}_{3}^{-}\right)$and phosphate $\left(\mathrm{PO}_{4}^{-}\right)$\}are in the order of $\mathrm{Ca}>$ $\mathrm{Mg}>\mathrm{Cl}^{-}>\mathrm{Na}>\mathrm{K}>\mathrm{NO}^{-3}>\mathrm{PO}^{-4}$.

HEAVY METALS (IRON FE, SILICON SI, ZINC ZN, LEAD PB, CHROMIUM CR, CADMIUM CD, Copper $\mathrm{Cu}$, Manganese, Mn, Fluorine F, and Boron B)

The concentrations of heavy metals are as follows: Iron $(\mathrm{Fe})$ ranged from $0.54-0.71 \mathrm{Mg} / \mathrm{l}$ with mean value of 0.61 $\mathrm{Mg} / \mathrm{l}$. Silicon (Si) ranged from $0.01-0.06 \mathrm{Mg} / \mathrm{l}$ with mean value of $0.02 \mathrm{Mg} / \mathrm{l}$. Zinc $(\mathrm{Zn})$ ranged from $0.01-0.09 \mathrm{Mg} / \mathrm{l}$ with mean value of $0.03 \mathrm{Mg} / \mathrm{l}$. Lead $(\mathrm{Pb})$ ranged from $0.002-0.004 \mathrm{Mg} / \mathrm{l}$ with mean value of $0.003 \mathrm{Mg} / \mathrm{l}$. Chromium ( $\mathrm{Cr}$ ) ranged from $0.006-0.021 \mathrm{Mg} / \mathrm{l}$ with mean value of $0.013 \mathrm{Mg} / \mathrm{l}$. Cadmium $(\mathrm{Cd})$ ranged from 0.002 $0.039 \mathrm{Mg} / \mathrm{l}$ with mean value of $0.022 \mathrm{Mg} / \mathrm{l}$. Copper $(\mathrm{Cu})$ ranged from $0.02-0.06 \mathrm{Mg} / \mathrm{l}$ with mean value of $0.028 \mathrm{Mg} / \mathrm{l}$. Manganese (Mn) ranged from 0.003$0.06 \mathrm{Mg} / \mathrm{l}$ with mean value of $0.024 \mathrm{Mg} / \mathrm{l}$. Fluorine $(\mathrm{F})$ ranged from $0.001-0.002 \mathrm{Mg} / \mathrm{l}$ with mean value of 0.002 $\mathrm{Mg} /$. Boron (B) ranged from $0.024-0.051 \mathrm{Mg} / \mathrm{l}$ with mean value of $0.026 \mathrm{Mg} / \mathrm{l}$. The concentrations of heavy metals (iron $\mathrm{Fe}$, silicon $\mathrm{Si}$, zinc $\mathrm{Zn}$, lead $\mathrm{Pb}$, chromium $\mathrm{Cr}$, Cadmium Cd, Copper $\mathrm{Cu}$, Manganese, Mn, Fluorine F, and Boron B) are generally low and similar to the report of Okoro et al.,(2017).Though, the concentrations of heavy metals are low, heavy metals can be poisonous at low concentration. 
Table 1: The Physical and Chemical Properties of Well Water in Gwagwalada Area Council Abuja

\begin{tabular}{|c|c|c|c|c|c|c|c|c|}
\hline Parameter & Dobi & Ibwa & $\begin{array}{l}\text { Paikon- } \\
\text { Kore }\end{array}$ & $\begin{array}{l}\text { Tungan } \\
\text { Maje }\end{array}$ & Zuba & Ikwa & Range & Mean \\
\hline Temp. $\left({ }^{\circ} \mathrm{C}\right)$ & 26.96 & 27.32 & 28.98 & 30.73 & 26.59 & 27.66 & $26.59-30.73$ & 28.04 \\
\hline $\mathrm{pH}$ & 8.14 & 7.17 & 7.41 & 7.92 & 8.01 & 8.23 & $7.17-8.23$ & 7.81 \\
\hline E.C $(\mu \mathrm{s} / \mathrm{cm} 3)$ & 354 & 242 & 254 & 254 & 240 & 222 & $222-354$ & 261.00 \\
\hline $\mathrm{TDS}(\mathrm{Mg} / \mathrm{l})$ & 14.45 & 13.16 & 12.97 & 13.08 & 12.14 & 21.54 & $12.14-21.54$ & 14.56 \\
\hline TSS(Mg/l) & 0.37 & 0.29 & 0.39 & 0.26 & 0.28 & 1.33 & $0.26-1.33$ & 0.49 \\
\hline Turbidity(NTU & 0.37 & 0.29 & 0.26 & 0.45 & 0.47 & 0.93 & $0.29-0.93$ & 0.46 \\
\hline Hardness(Mg/l) & 22.06 & 13.58 & 39.72 & 19.46 & 19.26 & 29.12 & $13.58-39.72$ & 23.87 \\
\hline $\mathrm{K} \mathrm{Mg} / \mathrm{l}$ & 4.03 & 4.06 & 4.13 & 4.16 & 5.09 & 3.05 & $3.05-5.09$ & 4.10 \\
\hline $\mathrm{Na} \mathrm{Mg/l}$ & 4.11 & 5.62 & 5.03 & 5.06 & 5.01 & 5.65 & $4.11-5.65$ & 5.08 \\
\hline $\mathrm{Cl}-\mathrm{Mg} / \mathrm{l}$ & 6.54 & 5.42 & 4.29 & 7 & 8.93 & 7.54 & $4.29-8.93$ & 6.62 \\
\hline $\mathrm{Mg} \mathrm{Mg/l}$ & 2.03 & 2.83 & 17.86 & 6.21 & 11.22 & 17.04 & $2.03-17.86$ & 9.53 \\
\hline $\mathrm{Ca} \mathrm{Mg} / \mathrm{l}$ & 20.03 & 10.75 & 21.86 & 13.25 & 8.04 & 12.08 & $8.04-21.86$ & 14.34 \\
\hline $\mathrm{NO}_{3}^{-} \mathrm{Mg} / \mathrm{l}$ & 1.83 & 0.96 & 1.82 & 2.53 & 1.75 & 1.47 & $1.47-2.53$ & 1.73 \\
\hline $\mathrm{Fe} \mathrm{Mg/l}$ & 0.62 & 0.71 & 0.62 & 0.55 & 0.54 & 0.64 & $0.54-0.71$ & 0.61 \\
\hline Si Mg/l & 0.01 & 0.02 & 0.017 & 0.03 & 0.02 & 0.06 & $0.01-0.06$ & 0.03 \\
\hline Zn Mg/l & 0.01 & 0.031 & 0.013 & 0.09 & 0.021 & 0.017 & $0.01-0.09$ & 0.03 \\
\hline Lead Mg/l & 0.002 & 0.003 & 0.004 & 0.002 & 0.004 & 0.003 & $0.002-0.004$ & 0.003 \\
\hline $\mathrm{Cr} \mathrm{Mg/l}$ & 0.014 & 0.006 & 0.011 & 0.011 & 0.013 & 0.021 & 0.006-0.021 & 0.013 \\
\hline $\mathrm{Cd} \mathrm{Mg} / \mathrm{l}$ & 0.005 & 0.002 & 0.013 & 0.031 & 0.042 & 0.039 & $0.002-0.039$ & 0.022 \\
\hline $\mathrm{Cu} \mathrm{Mg} / \mathrm{l}$ & 0.02 & 0.02 & 0.03 & 0.02 & 0.02 & 0.06 & $0.02-0.06$ & 0.028 \\
\hline $\mathrm{Mn} \mathrm{Mg} / \mathrm{l}$ & 0.006 & 0.044 & 0.011 & 0.022 & 0.003 & 0.055 & $0.003-0.06$ & 0.024 \\
\hline $\mathrm{F} \mathrm{Mg/l}$ & 0.002 & 0.001 & 0.001 & 0.002 & 0.002 & 0.002 & $0.001-0.002$ & 0.002 \\
\hline $\mathrm{B} \mathrm{Mg} / \mathrm{l}$ & 0.017 & 0.034 & 0.025 & 0.024 & 0.004 & 0.051 & 0.024-0.051 & 0.026 \\
\hline
\end{tabular}

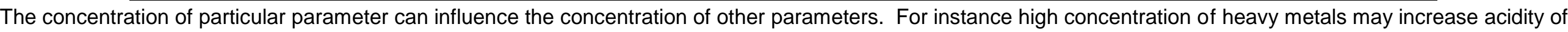
water. Thus, the twenty-three (23) parameters were correlated to determine the relationships that exist between parameters (Table 2). 
Table 2: Correlation Matrix of Well Water Properties

\begin{tabular}{llllllllllllllllll}
\hline Temp & $\mathrm{pH}$ & $\mathrm{EC}$ & $\mathrm{TDS}$ & $\mathrm{TSS}$ & Turb. & $\begin{array}{l}\text { Hard } \\
.\end{array}$ & $\mathrm{K}$ & $\mathrm{Na}$ & $\mathrm{Cl}-$ & $\mathrm{Mg}$ & $\mathrm{Ca}$ & $\mathrm{NO}_{3}^{-}$ & $\mathrm{Fe}^{2}$ & $\mathrm{Si}$ & $\mathrm{Zn}$ & $\begin{array}{l}\text { Cont' } \\
\mathrm{d}\end{array}$ \\
\hline
\end{tabular}

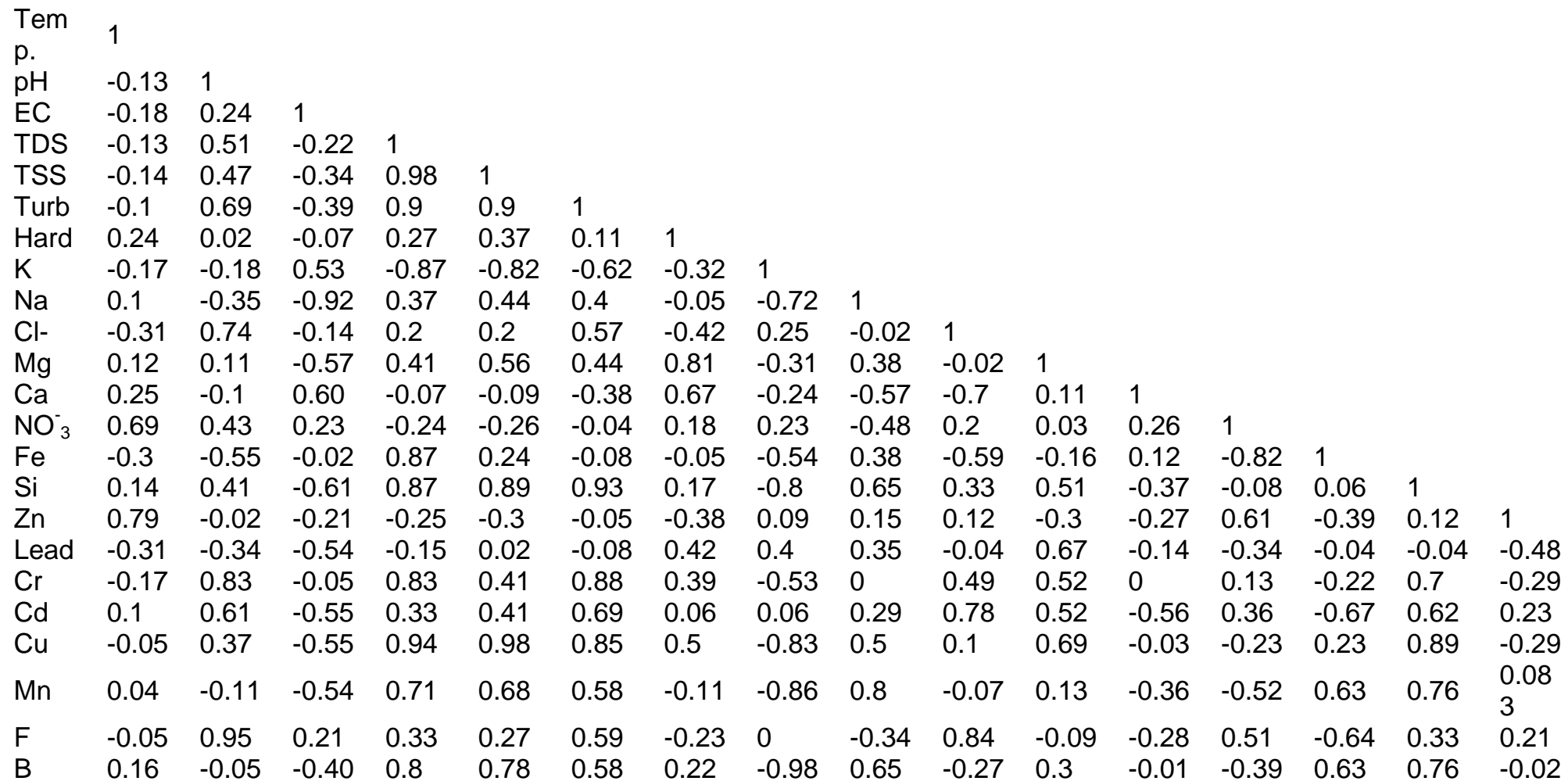




$\begin{array}{lllllll}\mathrm{Pb} & \mathrm{Cr} & \mathrm{Cd} & \mathrm{Cu} & \mathrm{Mn} & \mathrm{F} & \mathrm{B} \\ -0.05 & 1 & & & & & \\ 0.24 & 0.6 & 1 & & & & \\ 0.14 & 0.8 & 0.42 & 1 & & & \\ -0.15 & 0.23 & 0.06 & 0.66 & 1 & 1 & \\ -0.43 & 0.66 & 0.64 & 0.16 & -0.14 & -0.18 & 1 \\ -0.17 & 0.36 & -0.02 & 0.79 & 0.93 & \end{array}$

Table 2 present the correlation matrix of parameters. For examples, temperature has strong positive relationship with $\mathrm{NO}_{3}^{-}$and $\mathrm{Zn}(\mathrm{r}=0.69$ and 0.79$)$ respectively. $\mathrm{pH}$ has strong positive relationship with TDS, turbidity, $\mathrm{Cl}-, \mathrm{Cr}, \mathrm{Cd}$ and $\mathrm{F}(\mathrm{r}=0.51,0.69,0.74$, $0.83,0.62$ and 0.95 ) respectively. EC has strong negative correlation with $\mathrm{Na}, \mathrm{Mg}, \mathrm{Si}, \mathrm{Pb}, \mathrm{Cd}, \mathrm{Cu}$ and $\mathrm{Mn}$ $(-0.92,-0.57,-0.61,-0.54,-0.55,-0.55$ and -0.54$)$ respectively. TDS has strong positive relationship with TSS, turbidity, $\mathrm{Fe}, \mathrm{Si}, \mathrm{Cr}, \mathrm{Cu}, \mathrm{Mn}$ and $\mathrm{B}$.

Having correlated the parameters to determine their relationships, multiple regressions $(R)$ for the various correlation coefficients $(r)$ was computed to determine the overall strength of the parameters in ascertaining the quality of well water in the study area (Table 3).

Table 3: Coefficient of Determination of Water Quality Parameters

\begin{tabular}{ll}
\hline Statistics & Result \\
\hline Multiple Correlation $(\mathrm{R})$ & 0.98 \\
Coefficient of Multiple Determination $\left(\mathrm{R}^{2}\right)$ & $0.96(96 \%)$ \\
& \\
Standard Error of Estimate (SEE) & 0.005 \\
\hline
\end{tabular}

The Coefficient of Multiple Determination $\left(\mathrm{R}^{2}\right)$ being $96 \%$ means that the twenty- three water quality parameters tested can explain $96 \%$ of the overall water quality leaving only $4 \%$ unexplained. Thus, the variables are good enough to judge the well water quality in the study area. Thus, the suitability of the well water for domestic purpose was ascertained at $96 \% \pm 0.005$.

The Physical and Chemical Properties of Well Water
in Gwagwalada Area Council and Regulatory
Standard for Domestic Purpose.

Table 4 present the properties of well water in Gwagwalada Area Council and regulatory standard for domestic purpose.

Table 4:Properties of Well Water in the Study Area and Regulatory Standard for Domestic Purpose

\begin{tabular}{|c|c|c|c|c|}
\hline Parameters & Range & Mean & NSDWQ(2007) & $\begin{array}{l}\text { WHO Standard } \\
(2015)\end{array}$ \\
\hline Temp. $\left({ }^{\circ} \mathrm{C}\right)$ & $26.59-30.73$ & 28.04 & $<40$ & $>20<40$ \\
\hline pH & $7.17-8.23$ & 7.81 & $6.5-8.5$ & $6.5-9.2$ \\
\hline E.C $(\mu \mathrm{s} / \mathrm{cm} 3)$ & $222-354$ & 261 & $\geq 1000$ & $\geq 1500(\mu \mathrm{s} / \mathrm{cm} 3)$ \\
\hline TDS $(\mathrm{Mg} / \mathrm{l})$ & $12.14-21.54$ & 14.56 & 500 & 500 \\
\hline TSS(Mg/l) & $0.26-1.33$ & 0.49 & 500 & - \\
\hline Turb.(NTU & $0.29-0.93$ & 0.46 & $\leq 10$ & $\leq 5$ \\
\hline T. Hardness $(\mathrm{Mg} / \mathrm{l})$ & $13.58-39.72$ & 23.87 & 500 & 200 \\
\hline $\mathrm{K}(\mathrm{Mg} / \mathrm{l}$ & $3.05-5.09$ & 4.1 & & 100 \\
\hline $\mathrm{Na}(\mathrm{Mg} / \mathrm{l}$ & $4.11-5.65$ & 5.08 & 200 & 60 \\
\hline $\mathrm{Cl}-(\mathrm{Mg} / \mathrm{l}$ & $4.29-8.93$ & 6.62 & 250 & 5 \\
\hline $\mathrm{Mg}(\mathrm{Mg} / \mathrm{l}$ & $2.03-17.86$ & 9.53 & & 30 \\
\hline $\mathrm{Ca}(\mathrm{Mg} / \mathrm{l}$ & $8.04-21.86$ & 14.34 & 75 & 75 \\
\hline $\mathrm{NO}_{3}^{-}(\mathrm{Mg} / \mathrm{l}$ & $1.47-2.53$ & 1.52 & 50 & 45 \\
\hline $\mathrm{Fe}(\mathrm{Mg} / \mathrm{l}$ & $0.54-0.71$ & 0.61 & & 0.1 \\
\hline $\mathrm{Si}(\mathrm{Mg} / \mathrm{l}$ & $0.01-0.06$ & 0.03 & & \\
\hline $\mathrm{Zn}(\mathrm{Mg} / \mathrm{l}$ & $0.01-0.09$ & 0.03 & & 5 \\
\hline Lead(Mg/l & $0.002-0.004$ & 0.01 & & 1 \\
\hline $\mathrm{Cr}(\mathrm{Mg} / \mathrm{l}$ & $0.006-0.021$ & 0.013 & & 0.05 \\
\hline $\mathrm{Cd}(\mathrm{Mg} / \mathrm{l}$ & $0.002-0.039$ & 0.022 & & 0.01 \\
\hline $\mathrm{Cu}(\mathrm{Mg} / \mathrm{l}$ & $0.02-0.06$ & 0.04 & & 0.05 \\
\hline $\mathrm{Mn}(\mathrm{Mg} / \mathrm{l}$ & $0.003-0.06$ & 0.04 & & 0.5 \\
\hline$F(\mathrm{Mg} / \mathrm{l}$ & $0.001-0.002$ & 0.002 & & 0.9 \\
\hline $\mathrm{B}(\mathrm{Mg} / \mathrm{l}$ & $0.024-0.051$ & 0.03 & - & - \\
\hline
\end{tabular}

Table 4 shows the range and mean concentrations of water properties and the NSDWQ and WHO standard for domestic purpose. It shows water properties regulatory standard as follows: 


\section{Temperature and $\mathrm{pH}$}

The mean records of water temperature is $28.04^{\circ} \mathrm{C}$. This value is below the maximum limit of $\angle 40^{\circ} \mathrm{C}$ set by NSDWQ and also lies within the range $>20^{\circ} \mathrm{C}<40^{\circ} \mathrm{C}$ set by $\mathrm{WHO}$. The concentration of $\mathrm{pH}$ ranged from 7.178.23. The range is within the ranges of 6.5-8.5 NSDWQ and 6.5-9.2 standard set by WHO for domestic purpose. Thus, water from wells in Gwagwalada Area Council is safe for domestic purpose in terms of temperature and $\mathrm{pH}$.

\section{Electrical Conductivity $\left(\mathrm{E} . \mathrm{C} \mu^{\mathrm{s}} / \mathrm{cm}^{3}\right)$}

The electrical conductivity of well water in the area range $222-354 \mu \mathrm{s} / \mathrm{cm}^{3}$ with mean value of $261.00 \mu \mathrm{s} / \mathrm{cm}$ which is below $\geq 1000 \mu \mathrm{s} / \mathrm{cm} 3$ NSDWQ and $\geq 1500 \mu^{\mathrm{s}} / \mathrm{cm}^{3}$ standard set by WHO for domestic purpose. Thus, the EC of well water in Gwagwalada Area Council fall short of regulatory standard for domestic purpose. Therefore, water from Gwagwalada Area Council is not safe for domestic purpose in terms of EC.

\section{Total Dissolved Solids (TDS) and Turbidity}

The concentration of Total Dissolved Solids (TDS) is within the regulatory standard for domestic purpose. The TDS ranged from 12.14-21.54Mg/l. Thus, all values are below $500 \mathrm{Mg} / \mathrm{l}$ limit set by WHO. The mean concentration of turbidity was $0.46 \mathrm{Mg} / \mathrm{l}$. Thus, the turbidity of water in Gwagwalada Area Council is within acceptable limit of $\leq 5 \mathrm{NTU}$ set by WHO for domestic purpose and the $\leq 10$ NTU NSDWQ.

\section{Total Hardness}

Total hardness of all samples in Gwagwalada Area Council is within the NSDWQ and WHO standard for domestic purpose. Total hardness ranged from 13.58$39.72 \mathrm{Mg} / \mathrm{l}$. This range of value is below the maximum limits of $200 \mathrm{Mg} / \mathrm{l}$ set by $\mathrm{WHO}$ for domestic purpose and the $500 \mathrm{Mg} / \mathrm{l}$ National Standard for Drinking Water Quality. Therefore, water in Gwagwalada Area Council is safe for domestic purpose in terms of total hardness.

Mineral Nutrients ( $\mathrm{K}, \mathrm{Na}, \mathrm{Cl}, \mathrm{Mg}, \mathrm{Ca}$ and $\mathrm{NO}_{3}{ }^{-}$)

The concentrations of these minerals $\mathrm{K}, \mathrm{Na}, \mathrm{Cl}, \mathrm{Mg}, \mathrm{Ca}$, $\mathrm{NO}_{3}$ and $\mathrm{PO}_{4}$ in Gwagwalada Area Council were generally below their regulatory standard. Potassium (K)

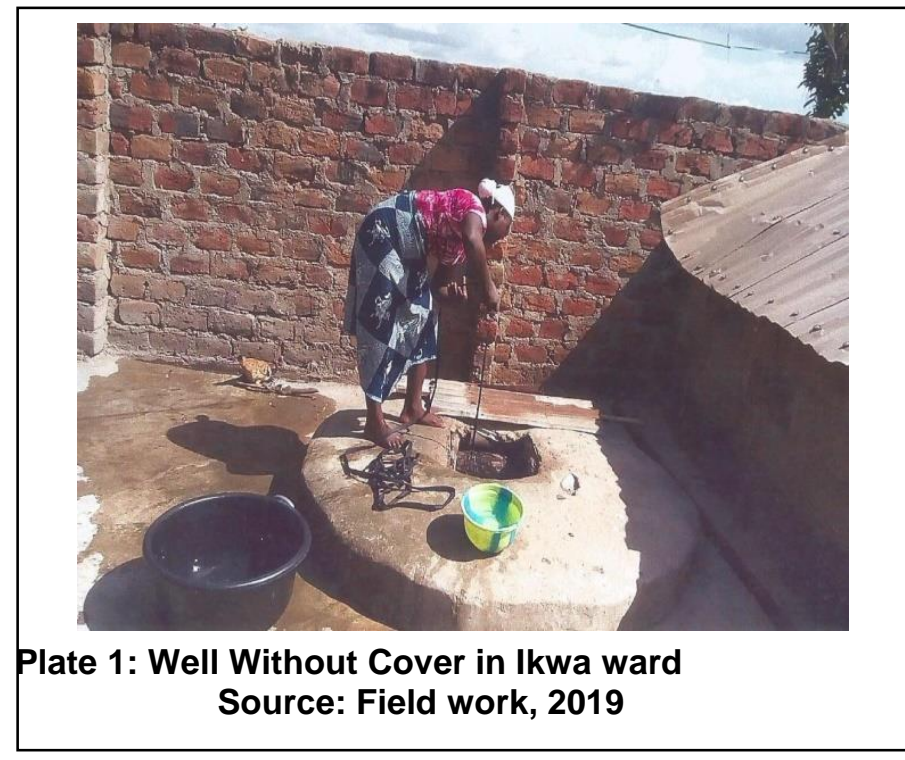

ranged from $3.05-5.09 \mathrm{Mg} / \mathrm{l}$ but $\mathrm{WHO}$ standard for domestic purpose is $100 \mathrm{Mg} / \mathrm{l}$. Sodium $(\mathrm{Na})$ ranged from $4.11-5.65 \mathrm{Mg} / \mathrm{l}$ but WHO standard for domestic purpose is $60 \mathrm{Mg} / \mathrm{l}$ and national standard is $200 \mathrm{Mg} / \mathrm{l}$. Chloride ranged from $4.29-8.93 \mathrm{Mg} /$ but NSDWQ is $250 \mathrm{Mg} / \mathrm{l}$. Magnesium $(\mathrm{Mg}$ ) ranged from $2.03-17.86 \mathrm{Mg} / \mathrm{l}$ but WHO standard for domestic purpose is $30 \mathrm{Mg} / \mathrm{l}$. Calcium (Ca) ranged from $8.04-21.86 \mathrm{Mg} / \mathrm{l}$ but WHO standard for domestic purpose is $75 \mathrm{Mg} / \mathrm{l}$. Nitrate $\left(\mathrm{NO}_{3}^{-}\right)$ranged from $1.47-2.53 \mathrm{Mg} / \mathrm{l}$ but WHO standard for domestic purpose is $45 \mathrm{~g} / \mathrm{l}$. Therefore, Water in Gwagwalada Area Council fall short of regulatory standard for domestic uses in terms of minerals $\mathrm{K}, \mathrm{Na}, \mathrm{Cl}, \mathrm{Mg}, \mathrm{Ca}$ and $\mathrm{NO}_{-}$.

Heavy Metals (Fe, $\mathrm{Si}, \mathrm{Zn}, \mathrm{Pb}, \mathrm{Cr}, \mathrm{Cd}, \mathrm{Cu}, \mathrm{Mn}, \mathrm{F}$ and B)

The concentrations of heavy metals in water in Gwagwalada Area Council were generally low but Fe and $\mathrm{Cu}$ fall short of regulatory standard for domestic purpose. The concentrations of Iron (Fe) were generally higher than the $\mathrm{WHO}$ standard of $0.1 \mathrm{Mg} / \mathrm{l}$ as it ranged from $0.54-0.71 \mathrm{Mg} / \mathrm{l}$. The concentrations of Zinc $(\mathrm{Zn})$ were generally lower than the WHO standard of $5 \mathrm{Mg} / \mathrm{l}$ as it ranged from $0.01-0.09 \mathrm{Mg} / \mathrm{l}$. Lead concentrations were also generally lower than the WHO standard of $0.05 \mathrm{Mg} / \mathrm{l}$ as it ranged from $0.003-0.004 \mathrm{Mg} / \mathrm{l}$. Chromium ranged from $0.006-0.021 \mathrm{Mg} / \mathrm{l}$ which is within the $\mathrm{WHO}$ set limit of $0.05 \mathrm{Mg} / \mathrm{l}$. Copper ranged from $0.02-0.06 \mathrm{Mg} / \mathrm{l}$ while the WHO set standard for domestic purpose is $0.05 \mathrm{Mg} / \mathrm{l}$, so sample(s)fall short of WHO set standard for domestic purpose. Thus, only well water from lkwa with mean value of $0.06 \mathrm{mg} / \mathrm{l}$ fall short of WHO set standard for domestic purpose (Table 1). Manganese $(\mathrm{Mn})$ ranged from $0.003-0.06 \mathrm{Mg} / \mathrm{l}$ while the $\mathrm{WHO}$ set standard for domestic purpose is $0.5 \mathrm{Mg} / \mathrm{l}$, so all samples in meet WHO set standard for domestic purpose. Fluorine $(F)$ was generally lower than the $\mathrm{WHO}$ standard of $0.9 \mathrm{Mg} / \mathrm{l}$ as it ranged from $0.001-0.002 \mathrm{Mg} / \mathrm{l}$.

The elevation of some heavy metal in well water was attributed to poor maintenance and poor sanitation witnessed mostly in Ikwa ward. Wells in Ikwa ward were not properly covered and some were covered with rusted metal cover (Plate1 and 2).

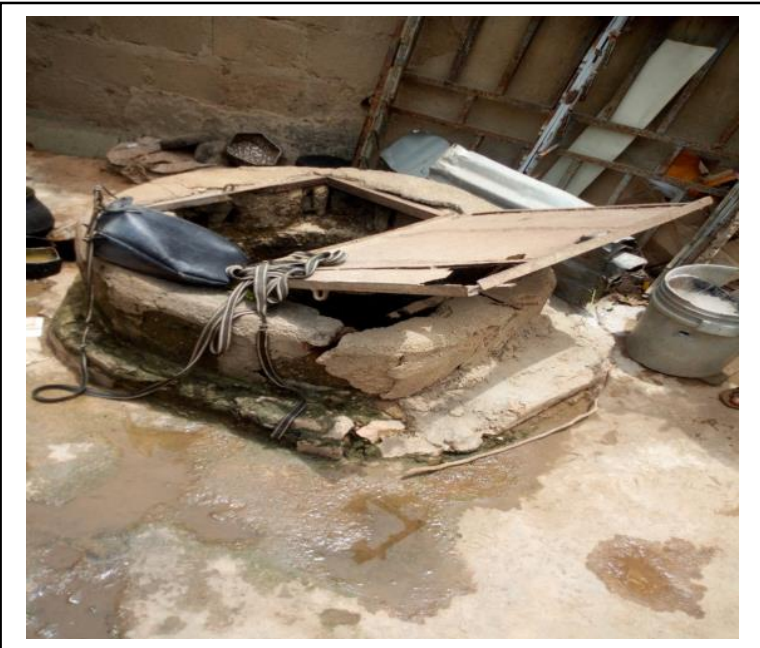

Plate 1: Well Rusted Metal Cover in Ikwa ward Source: Field work, 2019 


\section{CONCLUSION AND RECOMMENDATIONS}

It was concluded that well water in Gwagwalada Area Council are not safe for domestic purposes especially for drinking. Data from the survey shows that water samples generally had low electrical conductivity (222$354 \mu \mathrm{s} / \mathrm{cm}^{3}$ ), and nutrient but elevated concentration of some heavy metals. All samples fell short of regulatory standards in terms of $\mathrm{EC}, \mathrm{Fe}$ and $\mathrm{Cu}$, while well water from lkwa fell short of many heavy metals for domestic purposes.

The following recommendations were made based on findings of this study:

i. Since the result showed that well water in the study area fall short of regulatory standard for domestic purpose, Gwagwalada Area Council should a matter of urgency provide potable water to the residents to avert possible illness that may result from the consumption of untreated well water. Residents should be cautious of activities/factors (exposure, geological location and slope) capable of polluting well water within the area.

ii. Future study should be conducted on the sources of heavy metals in well water especially lkwa ward that fall short of many heavy metals for domestic purpose.

\section{REFERENCES}

Adeniyi, T. and Abdullateef, S., 2019. FAAC allocated N2.24bn to Gwagwalada Area Council in 7 months in 2019. Daily Trust newspaper Jan 21.

Akpan-Idiok, A. U., Ibrahim A. and Udo, I. A., 2012. Water Quality Assessment of Okpauku River for Drinking and Irrigation Uses in Yala, Cross River State, Nigeria. Research Journal of Environmental Sciences, 6: 210-221.

American Public Health Association APHA, 2005. Standard methods for the examination of water and wastewater. 21st ed. Washington D.C.: American Public Health Association.

Awaisu H. A., Ishaya K. S., Ogah A. T. and Shuaibu A., 2019. Evaluation of Water Quality of Domestic Water Sources in Nasarawa Town, Nasarawa Local Government Area, Nasarawa State, Nigeria. The Environmental Studies, 2(1):30-42.

Behailu T. W., Badessa T. S. and Tewodros B. A., 2017. Analysis of Physical and Chemical Parameters in Ground Water Used for Drinking around Konso Area, Southwestern Ethiopia. Journal of Analytical and Bioanalytical Techniques $8(5): 32-45$.

Chokpa, C., 2018. Urbanization and water supply challenges in Gwagwalada Federal Capital Territoiry Abuja Nigeria. Journal of Environmental Science and Toxicology 3(3):3943.
Chukwu O., 2008. Analysis of groundwater pollution from abattoir waste in Minna, Nigeria. Research Journal of Dairy Sciences, 2(4): 74-77.

Ezeribe, A. I., Oshieke, K. C. and Jauro, A., 2012. Physico-Chemical Properties of Well Water Samples from some Villages in Nigeria with Cases of Stained and Mottle Teeth. Science World Journal 7 (1):54-69.

Federal Capital Development Authority FCDA, 2018. The Geography of Abuja. Wikipedia. Jidauna, G. G., Barde, S. R., Ndabula, C., Oche, C. Y., and Dabi, D. D., 2017. Water Quality Assessment of Selected Domestic Water Sources in Dutsinma Town, Katsina State. Science World Journal, 12(No 4): 104-122.

Nigerian Standard for Drinking Water Quality (NSDWQ, 2007). Water quality guideline. Standard organization of Nigeria, Wuse, Abuja.

Kolo, B. I., Dibal, J. M. and Ndokawa, 1.1., 2009. Elemental Analysis of Tapwater and borehole water in Maiduiguri, Semi-arid region, Nigeria, European Journal of Applied Services, 1(2): 2629.

Okoro N., Omeje E. O., Osadebe P. O., 2017. Comparative Analysis of Three Borehole Water Sources in Nsukka Urban Area, Enugu State, Nigeria. Scientific and Academic Publishing, Resources and Environment, 7(4): 110-114.

Samaila K. I., Abubakar, M., Ujih O. U., Awaisu A. H. and Vincent T. I., 2015. Assessment of water quality of hand dug well in Vandeikya, Benue State, Nigeria. Journal of Natural and Applied Sciences, 4 (1): 67-82.

Shalom T, Obinna N. C Nwinyi C., Oluwadamisi A. and Vivienne N. E., 2011. Assessment of water quality in Canaan land, Ota, Southwest Nigeria. Agriculture and Biology Journal of North America, 2(2):2151-7517.

Segay T. and Haftom Z., 2016. Seasonal Variation in Physico-Chemical Parameters of Tekeze Reservoir, Northern Ethiopia. Animal Research International; Open Journal Systems Vol 13, No 2.

World Health Organization WHO, 2010, Guidelines for drinking-water quality - Volume 1: Recommendations Third edition, incorporating first and second agenda. World Health Organization WHO, 2015, Fact Sheets on Drinking Water. Available at http://www.Who.int/mediacentre/factsheets/fs39 1/en/. 